\title{
Retracing the Ritarian Roots: Talangpaz Sisters and Augustinian Recollects of San Sebastian Church
}

\author{
Emmanuel Luis A. Romanillos \\ Recoletos School of Theology, Philippines \\ elaromanillos@gmail.com
}

\begin{abstract}
This historical account retraces the roots of Saint Rita College that commenced its foundation totally unheralded in 1907. In the horizon, we find the foundresses of the Congregation of the Augustinian Recollect Sisters: Mother Dionisia de Santa María, Mother Cecilia Rosa de Jesús and the Augustinian Recollects of the San Sebastian Church in Manila. The two foundresses were blood sisters who left their hometown in 1719 and travelled to San Sebastian de Calumpang in Manila where the cherished icon of Our Lady of Mount Carmel. They found a small house in Bilibid Viejo where they lived a life of seclusion, contemplation and mortification. Their virtue and piety attracted the Augustinian Recollects of San Sebastian Convent. Not long after the Beaterio de San Sebastian was founded. It was 16 July 1725 when they lived as terciarias and followed the Rule of Saint Augustine under the protection of the Recollect religious of San Sebastian Convent. In 1907, the Recollect Fathers urged the sisters of the Beaterio to open a school for girls, after defraying the construction of the new edifice. And the Beaterio came in into being in 1907 Saint Rita Academy, later Colegio de Santa Rita, or Saint Rita College.
\end{abstract}

Keywords: Augustinian Recollect Sisters, Beaterio de San Sebastian, Colegio de Santa Rita, Talangpaz Sisters, Philippines

Date Submitted: February 8, 2019

Date Accepted: July 10, 2019

\section{Prologue}

Retracing the roots of a venerable institution or a prominent person somewhere in the remote past is indeed a great challenge posed to any historian who's worth the name. You pore over manuscripts, articles, periodicals, photographs and books, and try to put the puzzling pieces into place. You read the countless related sources and bibliographic data, and you try to make some sense of it. You need to put within your reach and utilize essential research tools like paleography, command of a foreign language (in our case, Spanish and Latin), fine dictionary, and knowledge of style 
that can help you understand what the whole thing is all about. However, you try to be objective at all costs after analyzing the sources and having to interpret the data at hand.

Oftentimes you have to sift through facts, contradictions, half-truths, conjectures, probabilities, prejudices or simple blunders in translation. At times you get to meticulously compare the sources. You customarily ask yourself: "Who copied whom?" "Who repeated whom?" "Who is more reliable?" "Who is contemporary or closer to the persons or events being analyzed?" You evaluate oral tradition as well. You read personal memoirs, diaries and letters and take them cum grano salis, with a grain of salt, at times.

You may find the truth in the end, and you relate to your readers, listeners, and fellow seekers of truth intelligibly. You relate to them in a language they can understand. And sometimes you succeed. And this is what I hope to do as I narrate to you the great effort as I try to retrace the roots of Saint Rita College that commenced unheralded in 1907: Mother Dionisia de Santa María, Mother Cecilia Rosa de Jesús and the Augustinian Recollects of the San Sebastian Church in Manila.

\section{Talangpaz progenitors of Calumpit, Bulacan}

Dionisia Mitas and Cecilia Rosa were natives of Calumpit, Bulacan, a parish managed by the friars of the Order of Saint Augustine. A Filipino biographer Luciano P. R. Santiago traced their lineage to principalía families in Pampanga and Bulacan in the $17^{\text {th }}$ century. Their father was Capitán Andrés Talangpaz y Mayari, twoterm gobernadorcillo of Calumpit. Their mother, Isabel Costanza Pamintuan y Panalangin, gave birth to six children, five girls and one boy, Miguel, who grew up to follow the footsteps of both father and grandfather as the town's chief executive. ${ }^{1}$

\section{Talangpaz sisters}

Dionisia Mitas, second daughter and third child of a brood of six, was born on 12 March 1691 and was baptized five days later. On an undetermined day and month in 1693, her younger sister was born, and she was baptized Cecilia Rosa on 26 July. When Archbishop Diego Camacho of Manila made a pastoral visit to Calumpit in 1699, both girls received the sacrament of Confirmation from him. Childhood period for the two sisters was uneventful. Presumably, they studied the rudiments of their education and Christian faith in a parochial school of their province. Dionisia Mitas and Cecilia Rosa steadily grew in piety.

Sensing their vocation to a life of seclusion and recollection, the sisters sought the Augustinian friar's assistance. They expressed their desire to live in prayer, contemplation and reclusion at Calumpit in a special way. They then begged this Augustinian parish priest to permit them to don the habit of mantelatas or terciarias according to the statutes of the Augustinian Third Order. Despite the sister's insistent pleas, the parish priest did not grant their wish for reasons unknown to us.

\footnotetext{
${ }^{1}$ Luciano P.R. SANTIAGO, The Stars of Peace. The Talangpaz Sisters (Manila 2001) 48-54.
} 
Divine Providence had other hidden plans for them, auspiciously notes the Augustinian Recollect Father Benito de San Pablo, a faithful chronicler of the Virgen del Carmen devotion and the Talangpaz sisters' earthly odyssey, in his 1747 chronicle entitled Tratado de cosas notables en el convento de San Sebastián [Treatise on Noteworthy Events in San Sebastian Convent]. ${ }^{2}$

The rejection no doubt caused anguish in the hearts and souls of both Dionisia Mitas and Cecilia Rosa. But it did not put an end to their prayer and mortification. It was just the first of a series of cruel tests of their vocation and heartrending travails the Talangpaz sisters had to undergo with nary a word of protest. With more persistence than ever, the two young women prayed to God and to the Holy Mother of Christ to show them the path to attain their goals in life to which they had set their mind and heart. For the Lord's counsel was: "Seek and you will find; ask and it will be given to you; knock and the door will be opened to you" (Mt 7:7). Father Benito de San Pablo tells us about a strange coincidence: "There was no prior mutual understanding between the two sisters for they themselves could not offer any explanation; all of a sudden they felt a very strong desire to submit themselves to the protection of our Lady of Carmel whose favors and prodigies were now very familiar to them." ${ }^{3}$

The Talangpaz biographer recounted that Dionisia Mitas and Cecilia Rosa left behind everything in Calumpit, their family, relatives, friends and ancestral home to tread the radical path of the Gospel in $1719 .{ }^{4}$ Doubtless they found consolation in the reassuring words of Christ Jesus: "Everyone who has left houses or brothers or sisters or father or mother or children or fields for my sake will receive a hundred times as much and will inherit eternal life" (Mt 19: 29). Father Benito de San Pablo goes on to say that they did not reveal to anyone their final decision to leave for the pueblo of San

\footnotetext{
${ }^{2}$ The complete title of the manuscript is Tratado de algunas cosas notables pertenecientes a los Conventos de Ministerios y administración espiritual de la Provincia de San Nicolás de Tolentino de Agustinos Descalzos de Philippinas. The original manuscript found its way into the library of the Pontifical University Urbaniana, Rome, Italy. A photocopy of the manuscript is now available at the Archivo Recoleto de Filipinas, Bulwagang Recoletos, Mira-Nila Homes, Quezon City.

${ }^{3} \mathrm{G}$. OCHOA, 34.

${ }^{4}$ Later chroniclers and documentary sources have accepted Father Benito de San Pablo's claim that the Talangpaz sisters arrived at the pueblo of San Sebastián de Calumpang towards the end of 1724. This would mean that the sisters had been living in the vicinity of San Sebastian Church, going to and coming from church, serving the Lord for a few months. The Recollect Historian General Father Gregorio Ochoa follows the 1724 line of Father Benito. Cf. BENITO DE SAN PABLo, Principio de la fundación y progreso del Beaterio de San Sebastián, extramuros de la Ciudad de Manila, de Agustinos Recoletos Descalzos, in Boletín de la Provincia de San Nicolás de Tolentino, 61 (1971) 171; G. OcHOA, 34. We accept the eyewitness account of Father Andrés de San Fulgencio who wrote the Fórmula y Método de gobierno para nuestras Beatas Agustinas de San Sebastián and defended the Beaterio from secular interferences in a petition to Governor General Fernando Valdés Tamón on 20 May 1735 and pointed to 1719 as the sisters' year of arrival at San Sebastian. See José GARCía DE SAN LORENZo MÁRTIR, Un Plantel de Sampaguitas en el Vergel Recoleto Agustiniano o la Congregación de Agustinas Recoletas Misioneras de Filipinas (Zaragoza 1954) 127-131.
} 
Sebastián de Calumpang. ${ }^{5}$ They had been living practically apart from their relatives as they had vowed to do after their rejection by the Augustinian priest of Calumpit. The Talangpaz biographer metaphorically portrayed them as "thirsty young does running toward the abundant fount of mercies of the most holy Virgen del Carmen to quench their spiritual thirst".

As soon as they set foot at San Sebastián de Calumpang, the sisters proceeded straightway to the shrine of the miraculous image of the Our Lady of Mount Carmel and prostrated themselves at the foot of her sovereign throne. It was an intensely poignant episode: they poured their hearts out in fervent prayer, unabashedly shedding copious tears of joy and expressing heartfelt thanks for all that Our Lady had thus far done to them. Dionisia and Cecilia Rosa renewed the offer earlier made at Calumpit to devote themselves totally to the service of the Blessed Mother. They begged the Divine Lady to cover them under her maternal protection and to shower them with her Son's bountiful blessings.

Their next move was to look for a small house where they could continue living a life of seclusion, contemplation, and mortification. In Bilibid Viejo at San Sebastian de Calumpang, they found the place they precisely wanted: so conveniently near the shrine of the Blessed Mother who would watch over them from a distance. During this time, they continued to wear ordinary street clothes like everyone else, but Dionisia and Cecilia Rosa would outshine everybody else in virtue and piety.

For a number of years, their daily schedule included some six hours of mass, prayer, and meditation as well as other devotions and spiritual practices in the church of San Sebastian "from the moment the church doors were opened to ten o'clock in the morning and in the afternoon from the hour of vespers till way past five" 6 . Their spirituality and lifestyle were basically sacramental: regular confession, daily Masses and frequent reception of Holy Communion. Their constant prayer intention was that "the Virgen del Carmen would willingly accept them as her daughters and handmaids." The sisters further offered their voluntary services for the daytoday physical upkeep of the shrine of their spiritual patroness.

\section{Enter the Augustinian Recollects}

The Spanish Augustinian Recollects of San Sebastián Convent were not deaf and blind to what they had observed about the Talangpaz sisters. Their exemplary life and conduct did not escape the attention of the Recollect friars. Certainly, the religious priests "noted with care their continued assistance in the church, frequency of the holy sacraments, their withdrawal and example in which they had lived outside. In all this care, it enkindled in them a loving propensity to encourage the two sisters in their holy exercises, to console them in their affliction, and to their perseverance in their good aims."

\footnotetext{
${ }^{5}$ Benito de SAN PABLo, 170.

${ }^{6}$ Benito de SAN Pablo, 171; G. Ochoa, 35.
} 
Before long, the Recollects appreciated the edifying lifestyle of the Talangpaz siblings. The missionaries likewise showed concern for the future beatas; they encouraged them to persevere in their laudable conduct and assisted them in their basic needs as well. This caused the sisters to disclose to the Recollects the reasons why they had come to San Sebastian under the watchful eyes of the Virgen del Carmen. Dionisia and Cecilia Rosa revealed that with the Virgin's succor they hoped to obtain what they had focused their heart and mind upon not very long ago: to don the habit of Augustinian Recollect tertiaries. The Recollects welcomed the idea, whereupon the Talangpaz sisters urged them to request the prior provincial to admit them as terciarias. The provincial-at that time Father Juan de San Andrés-was informed in due time of the sisters' excellent qualities and steadfast intentions. Their Recollect spiritual director Father Juan de Santo Tomás de Aquino corroborated the information only too gladly.

\section{Official Establishment of the Beaterio de San Sebastián}

By virtue of the Recollect Order's Constitutions, specifically the twin provisions of the Monialium ${ }^{7}$ and Ipsarum Mantelatarum, ${ }^{8}$ the prior provincial of the Recollects in the Philippines authorized the prior of San Sebastian convent to admit the sister ladies as members of the Third Order. ${ }^{9}$ On 16 July 1725, feast day of the Virgen del Carmen, Father Diego de San José, prior of San Sebastian, presided over the investiture rites of the Talangpaz sisters. It was a religious rite that was witnessed by massgoers and residents of San Sebastian de Calumpang.

The wide black wimple was imposed on their Recollect habit and cincture of the same color. As Christ and His Mother were part in their lives, they took the religious appellation Dionisia de Santa María and Cecilia Rosa de Jesús. They felt overjoyed that their cherished dream had at last become a reality. "An ineffable joy which they could only express with abundant tears of happiness and in stammering words," writes Father Benito de San Pablo. Sor Dionisia de Santa María and Sor Cecilia Rosa de Jesús, who had

\footnotetext{
7 My translation of the Monialum provision of 1664 Constitutions goes thus: "In Pope Clement VIII's time nuns were entrusted directly under the supervision of our Friars. In truth, the same observation can be made about mantelatas. And on account of it, we order that they are never admitted to the Habit unless they are women of good repute and proven virtue, are at least 40 years of age and have all what is necessary for subsistence lest they constitute a burden to the convents. However, they may not be admitted to the profession unless with the permission of Father Vicar general or with that of the Provincial with his counselors who after a very thorough evaluation when possible shall grant it. We further ordain that permission for the admission of the abovementioned mantelatas must be done beforehand, and reports about their lifestyle as well as their moral conduct must be made." See part II, Chapter 3, folio 55.

${ }^{8}$ Here's the Ipsarum Mantelatarum provision I translated from its Latin original: "We entrust the special supervision over mantelatas themselves to the Prior of the convent in close proximity (unless the Father Provincial may ordain otherwise) with the prerogative of designating one from the confessors of his community [family] for them, who shall be assigned for aims in accord with the apostolic authority granted to Friars, and it is known to have been instituted within our holy Order."
}

${ }^{9}$ G. OCHOA, 36. 
abandoned home and family, now officially belonged to the large family of men and women who lived according to the Rule of Saint Augustine on 16 July $1725 .{ }^{10}$

\section{Activities of the Beatas at the first Recollect-built House}

Father Diego de San José then constructed for them a small bamboo hut with thatched roof in a small clearing adjacent not far from the courtyard of the convent and church. ${ }^{11}$ This was aimed at segregating the new beatas to avoid unnecessary contact with the laity that could hinder their spiritual progress. Father Prior arranged their Ordo domesticus: community prayer, mass, and other devotions in the morning and late afternoon at the nearby Carmel shrine.

The rest of the day was devoted to embroidery and needlework from which they earned their daily bread. The observance of silence was strictly mandated, as it greatly aided in communing with God. The sisters' daily service to San Sebastian Church consisted in attending to the good order, cleanliness, and decency of God's temple. They further made by hand very fine Carmel scapulars for distribution to the Lady's countless devotees. ${ }^{12}$

The Beaterio de San Sebastian was thereby established with its original members. Its indisputable foundation date was 16 July 1725, the Talangpaz sisters' day of entry to the Third Order of the Augustinian Recollects. Not long afterward, two native women, impressed by the pair's good reputation of virtue and piety, presented themselves at the portal of their humble residence. Very soon two more applicants joined the burgeoning community. After having proven themselves worthy of the habit of the Third Order, they all sought the Recollect fathers' consent to wear it, which was likewise granted them at formal investiture rites. "The community of Recollect terciarias," declares Father Benito de San Pablo, "was already a formal body constituted by six fervent Sisters who lived a common life and took pleasure in spiritual detachment and in the practice of all virtues." 13

${ }^{10}$ Father Benito de San Pablo and Father Gregorio Ochoa refer to 16 July 1725 as the date of the foundation, and rightly so. See G. OCHOA, 36. The Decretum Laudis of 20 November 1970 of the Sacred Congregation of Religious of the Holy See has officially accepted this date. Father José García Martínez de San Lorenzo Mártir, however, points to another date-16 July 1728-after the demolition of their first residence and return to their old house. It was the new provincial Father Benito de San Pablo who ordered Father Cristóbal de la Soledad, the prior of San Sebastian, to allow them to don the habit of the mantelatas once more and to take care of them in accordance with the Constitutions. Father Diego de San José again built a house where the Talangpaz sisters would reside. Thus, it was on 16 July 1728 when the sisters were once more given the habit at the church of San Sebastian. José GARCíA DE SAN LORENZO MÁRTIR, En torno al Beaterio de San Sebastián, en Boletín de la Provincia de San Nicolás de Tolentino, 42 (1952) 62-63.

${ }^{11}$ The lowly house was built because the Recollects "either wanted to award the mantelatas for the prolonged services to the shrine of San Sebastian or they wanted them to be near God's temple and be protected from mundane dangers."

12 Patricio Marcellán, Provincia de San Nicolás de Tolentino de Agustinos Descalzos de la Congregación de España e Indias (Manila 1879) 29.

${ }^{13} \mathrm{G}$. ОСНOA, 38. 
The fact that Mother Dionisia and Mother Cecilia Rosa had sought affiliation with the Augustinian Recollects and governance by the Rule of Saint Augustine indicated in no uncertain terms the coenobitic character of the nascent beaterio. Such conventual and communitarian spirit was further enhanced and crystallized by the subsequent admission of four ladies, thus constituting the primitive community of what would become in the course of centuries the Congregation of the Augustinian Recollects Sisters.

\section{Gauntlet of trials and contradictions}

The incipient community was very soon dissolved by no less than the irascible prior of San Sebastian himself. The hut near San Sebastian church was torn down. Defrocked and distraught, the sisters went back to the old residence in Bilibid Viejo and the other terciarias returned to their respective families.

This sad episode in the Beaterio's existence was deemed a "terrible contradiction" for the sisters. ${ }^{14}$ It was one of those trials and travails that often assailed the spiritual progress of people on the road to sanctity. What Father Diego de San José did was to save the unity and harmony in his own religious community which had been wracked by factionalism arising from admission polemic. One faction favored the optimistic view wherein entry to the beaterio should not be unhampered. Divine Providence would take care of their subsistence. The opposing group held on to the belief that the Order's Constitutions which banned uncontrolled admission ought to be followed to the letter. Beaterio applicants without any means of subsistence would constitute additional burden to San Sebastian Convent. The financial misfortunes of the Saint Nicholas province had been caused by constant Moro raids of their missions and parishes. Apparently, this group prevailed.

Dionisia and Cecilia Rosa saw in this "contradiction" as another great opportunity to truly discern their divine call. Their life of prayer in the Beaterio changed because of this rough interruption. Father Benito de San Pablo again describes for us what they did afterward:

In full conformity to the will of God, they worshipped His inscrutable plans and continued to keep themselves constant and persevering in their first vocation, clinging on to the firmest hope in the protection of the Virgen del Carmen who will confirm their intentions and hearken to their pleas. ${ }^{15}$

\section{Rehabilitation on 16 July 1728}

Upon his election as provincial in April 1728, Father Benito de San Pablo, aware of the exemplary "behavior and character" of the two sisters, acceded to the favorable recommendation of the friars in San Sebastian. He thereupon ordered the new prior Father Cristóbal de la Soledad to readmit them as terciarias and to shelter them in a new residence which would be constructed for them by Father Diego de San José himself.

On 16 July 1728 the devout pair donned the habit once more. Before Father Cristóbal de la Soledad, the sisters knelt before the altar, and in his presence swore in a pious manner to live according to the Rule of Saint Augustine and the Constitutions of

\footnotetext{
${ }^{14}$ Ibid., 36.

${ }^{15} \mathrm{G}$. OCHOA, 39.
} 
the Tertiaries of the Augustinian Recollect Order. They wore the habit of the tertiaries or beatas thereafter. ${ }^{16}$

The beatas all the more intensified their prayer life and mortification. Their reception of the sacraments became more frequent. In the San Sebastian church, they spent more time before the "throne of the Queen of Carmel," shedding copious tears and expressing fervent petitions not to be left abandoned because they "never wanted to belong to anybody but to her and to her Divine Son." ${ }^{17}$

\section{Subsistence and number of tertiaries grew}

A large house was built for them in San Sebastian. They were, as prophesied, joined by young women until, around 1732 when the beatas formed a community of thirteen. For the beatas' sewing and embroidery work, the Beaterio was given 23 pesos a month and 100 cavans of palay a year by the Recollects of San Sebastian, plus another 25 pesos a month and 200 cavans of palay from San Nicolás Convent in Intramuros. ${ }^{18}$

A group in Manila soon publicly denounced this re-established Beaterio. The grave charges were: "...that some girls in the beaterio were there without their parents' consent; that the girls were forced to make a vow of chastity against their will; that the beatas lived in community against the law and to the prejudice of the State, which had to support them; and that all this scandalized the city of Manila, which could not view, without indignation, the privations and miseries suffered in the beaterio by girls from prominent families."19 In the end, the charges turned out to be baseless and bereft of truth.

\section{Mother Dionisia and Mother Cecilia Rosa returned to the Father}

The younger foundress Mother Cecilia Rosa returned to her Maker on 31 July 1731 after a lingering illness. She had professed the evangelical vows of poverty, chastity and obedience on 11 March 1731 in the presence of San Sebastian prior Cristóbal de la Soledad. A Spanish biographer dubs her "the Little Flower of the Beaterio de San Sebastián," patterned after Saint Therese of the Child Jesus, the Little Flower of Lisieux. ${ }^{20}$

On 12 October 1732, Mother Dionisia, the first superior of the Beaterio, passed away in the odor of sanctity. Six days earlier, she had professed the three evangelical counsels. Mother Dionisia de Santa María was thereupon succeeded by Mother Margarita de Santa Mónica. The beata from Arayat, Pampanga, administered the Beaterio until her demise in 1748.

\footnotetext{
16 J. García, Un Plantel de Sampaguitas, 91.

${ }^{17}$ G. OCHOA, 38.

${ }^{18}$ Nick JOAQuín, Culture and History, in Compilation of Documents on the Life, Virtues and Reputations of the Servants of God Mother Dionisia de Santa María and Mother Cecilia Rosa de Jesús (Manila 2002) 233. The compilation was a collaborative work of Fr. Emilio Edgardo A. Quilatan OAR, Luciano P.R. Santiago and Emmanuel Luis A. Romanillos, members of the Historical Commission of the Beatification Cause of Mother Dionisia and Mother Cecilia Rosa Talangpaz.

${ }^{19}$ Ibid., 233-234.

20 J. García, Un Plantel de Sampaguitas, 92.
} 


\section{The Recollects to the rescue}

In a communication requesting a license dated 20 May 1735 to the governor general Fernando Valdés Tamón, the prior provincial Father Andres de San Fulgencio had only good words to the sisters. He declared that the beatas could freely leave the primitive convent anytime and anywhere but they voluntarily refrained from it, instead they devoted their time to the service of Our Lord God and to His most holy Mother of Carmel and to the frequent reception of the sacraments to the edification of all the faithful, "for which they come to the church always and when convenient to them." ${ }^{21}$ Their food was solely at the expense of the mercy and alms of the impoverished San Sebastian convent and shrine of Our Lady of Mount Carmel. Some noble and pious residents of Manila promised to provide them with sources of income once the Beaterio's stability was achieved. It was and never would be the intention of Saint Nicholas Province or its subjects to harm the royal rights of the Patronato Real. Its only objective was to "foment the spirit of said mantelatas for the greater honor of God, of His most holy Mother and the welfare of their souls."22

After the deliberation, on 17 June 1735, the Royal Audiencia, the Fiscal of the Audiencia and Governor General Valdés Tamón granted the license to the province to maintain a house of young women devoted to prayer in an exemplary contemplative and communitarian lifestyle, collegialiter, as well as withdrawn from mundane affairs. Evidently, there was no royal license yet before it.

\section{Recollect writers view the Talangpaz sisters}

The Augustinian Recollect writers highlighted the exemplary life of Christian virtue and prayer of the Beaterio foundresses Mother Dionisia and Mother Cecilia Rosa. ${ }^{23}$ From the earliest documents on the Talangpaz sisters written by the Recollects, we observe the young Bulakeñas' love for detachment from the world, symbolized by their wearing of the habit of the Augustinian beatas. We especially view their propensity for prayer and meditation, especially amid tribulations. Some writers focus on their remarkable patience and perseverance during trials and adversities. A $20^{\text {th }}$-century author stresses their love for manual work.

Father Benito de San Pablo provides us with a poignant description of their commitment to religious poverty and detachment from material things and concerns. The theological virtues of faith, hope and charity were likewise visibly mirrored in their daily lives. Their frequent reception of Sacraments was further stressed. Their Marian spirituality is clearly pictured for us by the Recollect writers. It was their love for the Mother of God under the invocation of the Virgen del Carmen that led them to her shrine at San Sebastian Church, "like thirsty young does they ran to drink and quench their thirst in the everlasting founts of mercies of the most holy Virgin of Carmel." ${ }^{24}$

${ }^{21}$ Francisco MORENo, Instrucciones para las Hermanas Mantelatas, o Terceras del Orden de Recoletos de Nuestro Padre Agustín, y otros documentos referentes al Beaterio (Tambobong 1894) 59; J. García, Un Plantel de Sampaguitas, 128.

${ }^{22}$ F. MORENo, Instrucciones, 59.

${ }^{23}$ Emmanuel Luis A. Romanillos, The Talangpaz Sisters in the Eyes of the Augustinian Recollect Writers, a paper read in a symposium on 18 July 2001 at the Saint Rita College Auditorium, Manila.

${ }^{24}$ G. OCHOA, 34. 


\section{Fr. José Abel Salazar's views}

According to Father José Abel Salazar, erstwhile secretary general of the Augustinian Recollect Order, who, besides stating that the foundation year was 1725 , wrote the following entry in the Dizionario degli Istituti di Perfezione in 1974: "The special objective that the Institute strives for since 1754 was the Christian education of the young girls, without excluding at all their service to the Church in missions and other apostolic works within the limits of their means and capacity. The legislation, revised by the special general chapter, does not offer peculiar aspects worth mentioning."

Father Salazar clearly stresses that the spirituality of the Augustinian Recollect Congregation is that of the Order of Augustinian Recollects, to which the sisters in the Philippines are closely bonded since their origins."25

\section{Threats against the survival of the Beaterio}

Francisco José de Ovando y Solís, ${ }^{26}$ the first Marqués de Ovando (1693-1755) was governor-general of the Philippines in 1750-1754. He extended the royal patronage's protection over the Beaterio. In the end, he exempted it from all royal tributes.

General Marqués de Ovando had earlier issued an order on 15 July 1754 mandating the immediate inclusion of the occupants in the royal census for tribute purposes, the discontinuance of the use of beatas, terciarias, or mantelatas, of any religious appellation, and of the wimple, habit and cloister, the limitation of the number of occupants, and the ban of the use of Tagalog within the Beaterio premises. He further ordered the continuation of teaching activities in schools by those he termed ladinas, referring to the beatas who were proficient in both Tagalog and Spanish. ${ }^{27}$

The governor-general then dispatched his representative to pay a visit to the Beaterio and later to report the results of his visit directly to him. The fiscal of the colonial government had earlier insisted that the beatas should pay the royal tributes. However, Marqués de Ovando recalled his previous order, eventually made the Beaterio exempt from all taxes and reported all what he did to the Spanish monarch. At his royal palace at Aranjuez in the Spanish province of Madrid, King Ferdinand VI (17131759) then issued a real cedula on 26 May 1756 that sanctioned all the official acts and recommendations by his vice royal patron at the colonial capital. ${ }^{28}$

Marqués de Ovando's subsequent solicitude for the terciarias may be deduced from the fact that he was an active member of the Third Order of Saint Francis of Assisi.

25 José Abel SAlazar, Agostiniane Recollette, delle Filippine, Hermanas Agustinas Recoletas, Augustinian Recollect Sisters (AR) in Dizionario degli Istituti di Perfezione I (Rome 1974) 239240. The same dictionary entry was translated into Spanish as Agustinas Recoletas, de Filipinas, Hermanas Agustinas Recoletas, Augustinian Recollect Sisters, and was published in Boletín de la Provincia de San Nicolás de Tolentino, 74 (1984) 59-60.

${ }^{26}$ Javier ORTIZ DE LA TABLA DUCASSE, El Marqués de Ovando, Gobernador de Filipinas (1750-1754) (Sevilla 1974), 27. Named governor general in 1746, he took possession of his office in Manila on 20 July 1750 and was succeeded by Pedro Manuel de Arandía on 19 July 1754.

27 Licinio RuIz, Sinopsis histórica de la Provincia de San Nicolás de Tolentino de las Islas Filipinas de la Orden de Agustinos Recoletos I (Manila 1925) 624-625; J. GARcíA, Un Plantel de Sampaguitas, 20-21.

28 J. GARCíA, Un Plantel de Sampaguitas, 131-132. 
His last will and testament provided for the burial of his body wearing the habit of Saint Francis. His second child María Manuela, who was born in Manila in 1753, later became a Dominican nun at the Convent of Santa Rosa in Puebla de los Angeles, Mexico. ${ }^{29}$

\section{Inklings of the educational apostolate of the Beaterio}

A month earlier, on 14 June 1754 Marqués de Ovando ordered an escribano Vicente López Pilares to visit the Beaterio and select from the beatas those most qualified and prepared to teach. Chosen were Sister Nicolasa de San José, superior of the beaterio since 1748; Sister Ignacia de la Santísima Trinidad; and Sister Clara de Santa Rita. This was the first inkling, the initial proof that the beatas were tasked with the teaching mission. ${ }^{30}$

\section{San Sebastian prior as director of Beaterio (1811)}

The second implicit proof that some kind of teaching was being done at the Beaterio and elsewhere can be found in an ordinance of the 1811 provincial chapter of Saint Nicholas Province which had entrusted to the local prior of San Sebastian Convent the "inspection and spiritual direction of the Beaterio." The local prior was tasked to see to it that the instructions issued by the provincial chapter to the Beaterio were complied with and implemented. This had been the practice since time immemorial.

In this ordinance, the provincial chapter urged the prior of San Sebastian to report anything "that happened in the Beaterio against the good conduct, decorum, contemplation, temporal administration, etc., that must always reign in a house of recollection of adult persons so desirous of eternal salvation and of the niñas educandas (young female students) entrusted to their care and protection." ${ }^{11}$

\section{Permit issued to San Sebastian prior on Easter precept}

The third implicit proof was in 1814. In that year Father Mariano de San José, prior of San Sebastian Convent in 1812-1815, ${ }^{32}$ had asked the necessary permission from Fray Juan Antonio de Zulaibar, O.P., Archbishop of Manila (1805-1824), for both the poor and the well-to-do niñas educandas as well as for the 12 members of the Beaterio to observe the annual Easter precept of Holy Communion and Confession at San Sebastian Church which would be most convenient for their "calm, tranquil, and spiritual well-being."

Through the secretario de cámara y de gobierno Father Raymundo Roxas, the Dominican prelate answered Father Mariano de San José on 15 March 1814 that for the "best economic management and spiritual welfare of the niñas educandas del

\footnotetext{
${ }^{29}$ Ibid., 241.

${ }^{30}$ Ibid., 21.

${ }^{31}$ F. MORENO, Instrucciones, 72.

${ }^{32}$ Francisco SÁDABA, Catálogo de los Religiosos Agustinos de la Provincia de San Nicolás de Tolentino de Filipinas desde el año 1606, en que llegó la primera misión, hasta nuestros días hasta 1906 (Madrid 1906) 366.
} 
Beaterio" he granted the necessary permit for "said young girls" to comply with the Easter obligations at San Sebastian Church of the Recollect fathers. ${ }^{33}$

\section{A pure-blooded Spanish beata and teacher}

Not all those who entered the Beaterio de San Sebastián were Filipino native women. An española insular, Madre Melchora de Santa Tersera was a beata who was born in the Philippines and whose father and mother were both Spanish. She professed the religious vows before the prior Father Francisco Vidal de San José in 1835 on the birthday of her spiritual Father Saint Augustine, $13^{\text {th }}$ day of November.

Madre Melchora was a very learned beata, well prepared for teaching. Indeed, she was the maestra de las niñas del Beaterio, teacher of the young girls of the Beaterio. She exercised her teaching profession for some 13 years. The Spanish beata breathed her last on 24 September $1847 .^{34}$

\section{Archbishop O'Doherty: "Teaching is Beaterio's second goal"}

On 19 August 1929, Michael J. O'Doherty, archbishop of Manila, decreed the erection and approval of the Instituto de las Hermanas Terciarias Recoletas de Filipinas as a religious congregation of diocesan right. He describes the events leading to the decree of establishment and points out among others that: "The goal of this Institute or religious state is not only to assure the salvation of one's own soul by complying with the precepts of the Lord and fleeing from the perils of the world but also by acquiring perfection of the virtue, holiness, by following the evangelical counsels, in particular the sublime advice of the Divine Master when he told his disciples: 'Be perfect, even as your heavenly Father is perfect'." 35 Archbishop O'Doherty then states: "The secondary goal [of the Beaterio de San Sebastian] is the teaching, education, and care of girls."

\section{The birth of Colegio de Santa Rita}

From the very decree of erection and approval by Archbishop Michael J. O'Doherty we find more details of the unheralded beginnings of Saint Rita College. After the strong earthquake that struck Manila and environs in 1880, the old Beaterio had to undergo major repairs. The year 1881 saw a refurbished Beaterio rising from its ruins.

Decades later, on February 1906 the provincial council of Saint Nicholas of Tolentino Province in a session on 22 February 1906 urged the prior provincial to make a study of what can be done to the Beaterio-Colegio de Santa Rita with respect to the proposal of the construction project at the Beaterio.

The provincial council met again on 3 August of the same year 1906 and approved the blueprints and budget for the construction works at the Beaterio. It further considered as very appropriate and convenient the decision of the prior provincial

${ }^{33}$ F. Moreno, Instrucciones, 70-71. The $15^{\text {th }}$ March 1814 is the date of archbishop's response to the request to the Recollect's letter, not the date of Father Mariano de San José's letter, as erroneously translated or affirmed by Sister Bernardita VILLAMOR in her work Congregation of the Augustinian Recollect Sisters (AR). Past and Present (Manila 1991) 8.

${ }^{34} \mathrm{~F}$. MORENO, Instrucciones, 74.

${ }^{35}$ See Archdiocesan Archives of Manila, 39.b.4: Folder 12-Augustinian Recollect Sisters. The pertinent document is now part of the Compilation of Documents, 304-306. 
Father Tomás Roldán to open a free school for girls in the Beaterio-Colegio de Santa Rita. The sum of 18,000 pesos was the approved budget for the expansion project. By the end of May 1907, the construction and painting of the whole building were over. The new conventual chapel was blest and inaugurated on the $2^{\text {nd }}$ day of June. ${ }^{36}$ The incumbent superior Mother Toribia de la Paz had longed for this day. In her second term in 1905-1908 [having been superior in 1878-1893], this dream came true. A sung mass with a fitting sermon was celebrated. The rooms and halls of the new building were all blest in a most solemn manner.

The Blessed Sacrament was taken in a procession to the new chapel or semipublic oratory in the second floor where it was permanently kept for adoration by both sisters and pupils. Thereafter a Recollect priest who served as chaplain celebrated mass daily at the chapel. ${ }^{37}$

In that same month of June, the school for girls was opened. ${ }^{38}$ Thus started the first formal education in the teaching tradition and apostolate of the Augustinian Recollect Sisters. The school enrolment then was 30 young girls in 1907. By 1910, the number had gone up to 130. By 1928, the school_called Saint Rita Academy since 1921 and with its primary and secondary courses approved by the Bureau of Private Schools, had increased to 200 externs and interns. On 23 July 1928, the provincial council decided to officially donate and cede to the religious of the Beaterio de San Sebastian the property of all the lot where the school edifice stood, its dependent properties and the whole land parcel occupied by the convent of the women religious. ${ }^{39}$

\section{The legacy of education spreads to Cavite City}

The apostolic delegates of the Roman Pontiff [later papal nuncios] regularly visited the mother-house and constantly exhorted the sisters to work for the education of the youth. At one time, the total of 150 girls studied at the Colegio de Santa Rita in accordance with Catholic principles and with rigid government requirements. Shortly afterward, the authorization to open another school was granted.

Colegio de Santa Mónica was opened in Cavite City in 1910. The sisters also managed a residence of female interns and boarders who studied in government schools. They further administered a free school where they taught religious instruction and prepared about 75 girls and boys for Holy Communion. The Second World War obliterated the school buildings but not the memory of those three pioneering sisters: namely, Sister Genoveva del Santísimo Sacramento, who was superior of the Beaterio in 1900-1905; Sister Teresita de San José; and Sister Eulogia de los Dolores.

\footnotetext{
${ }^{36}$ Archdiocesan Archives of Manila, 39.b.4: Folder 12-Augustinian Recollect Sisters. See also Compilation of Documents, 304. It was not on 1 June 1907, as claimed earlier by Luciano P.R. Santiago, in The Talangpaz Sisters; Foundresses of the Beaterio de San Sebastián de Calumpang (Now the Congregation of the Augustinian Recollect Sisters), in Recollectio 13 (1990) 90. This error is repeated in his The Stars of Peace. The Talangpaz Sisters (Manila 2001) 128-129.

${ }^{37}$ Ricardo JaRAUtA, Album de la Orden de Agustinos Recoletos (Zaragoza 1931) 82.

${ }^{38}$ See Compilation of Documents, 304-306.

39 Ibid., 311.
} 


\section{The name Beaterio de Santa Rita}

The name Beaterio de San Sebastián was found in every document prior to 1909. After this year, the Recollect superiors in their documents started calling it Beaterio de Santa Rita, while maintaining indistinctly the names Beaterio de San Sebastián, Colegio-Beaterio, or Colegio de Santa Rita [St. Rita Academy, Saint Rita College]. Three circumstances brought about the indistinct use of the name.

\section{A school of that name had been opened at the Beaterio}

The Recollect vicar provincial Father Fernando Hernández on $1^{\text {st }}$ March gave a book Libro del Beaterio de Santa Rita to the sisters, whose purpose was to compile all the official documents, communications and appointment papers;

The same vicar provincial in the name of the whole Province of Saint Nicholas donated to them and installed an image of the Augustinian Saint Rita of Cascia who was the titular patroness of the chapel.

The prior general Father Gerardo Larrondo in a letter to the archbishop of Manila dated 14 June 1928 called it Beaterio of the Augustinian Recollect Tertiaries of Manila. Months later, on 19 September, he called it Beaterio de Santa Rita once more. By 1932, two different names were definitely and unmistakably used: Saint Rita College and Motherhouse of the Congregation of the Augustinian Recollect Missionaries of the Philippines. ${ }^{40}$

\section{Epilogue}

The Servant of God Mother Dionisia de Santa María once expressed what they felt to the prior of San Sebastian in the wake of that crucible of contradiction: "If you repudiate and dismiss us now, be assured that afterward you shall receive the two of us, that you shall give the holy habit to us and later on to others as well. They shall be brought by the Virgen del Carmen to give us company. And we are hopeful to acquire this from our Divine Mother who shall grant it to us with great joy and much happiness to be shared by the fathers. Our fate for now is to have patience and to suffer until God and His most holy Mother shall have mercy on us." ${ }^{41}$

Indeed, Mother Dionisia's prophetic words became a reality through the everpresent assistance of the Divine Providence and of the Lady of Mount Carmel. The prophecy continues to be fulfilled as hundreds of Filipino women from all walks of life, whose earnest desire is to seek sanctification and serve the Holy Mother Church in a selfless manner, have ceaselessly come to and professed the evangelical counsels before God Almighty at the revered shrine of the Virgen del Carmen, San Sebastian Church of the Augustinian Recollect religious priests and brothers.

The Augustinian Recollect Sisters today as ever share the common spirituality and legacy of their great Father Saint Augustine that consists of caritas veritatis, love for the truth, expressed in withdrawal, contemplation, study of the Scriptures, personal sanctification, and necessitas caritatis, demands of charity, when asked by the Holy Mother Church. Like a true daughter of Saint Augustine, the religious sister must know how to renounce her otium (leisure), even with good judgment and only if the Church

\footnotetext{
40 José GARcía, En torno al Beaterio de San Sebastián, 159-160.

${ }^{41}$ Benito de SAN PABLo, 176.
} 
requires her services in her apostolate and service to her people (negotium). Thus, the Augustinian Recollect sister engages in various fields of the apostolate, most especially in the age-old educational apostolate that retraces its historical origins to the early native women mantelatas or terciarias of the Beaterio de San Sebastian.

It is a wonderful blessing from God Almighty and through the intercession of the Virgen del Carmen to find now in the bosom of what was then Beaterio de San Sebastian this venerable institution named Saint Rita College on the threshold of its centenary, raring to go and live on to face the challenges of the coming decades.

\section{SOURCES AND BIBLIOGRAPHY}

\section{A. Published Primary Sources}

Benito de San Pablo. Principio de la fundación y progreso del Beaterio de San Sebastián, extramuros de la Ciudad de Manila, de Agustinos Recoletos Descalzos, in Boletín de la Provincia de San Nicolás de Tolentino, 61 (1971) 163-183.

\section{B. Articles}

Angel MARTínez CUESTA. Monjas y beatas en Filipinas, 1621-1898, in Primer Congreso Internacional del Monacato Feminino en España, Portugal y América (1492-1992) I 511-520.

Emilio Edgardo A. QUILATAN. The Congregation of the Augustinian Recollect Sisters: Spirituality of the Beaterio de San Sebastian, in Recoletos: History, Legacy and Culture, Quezon City 2004, 121-130.

Emmanuel Luis A. Romanillos. The Talangpaz Sisters in the Eyes of the Augustinian Recollect Writers. A paper read in a symposium on 18 July 2001 at Saint Rita College Auditorium, Manila.

\section{Books}

Manuel CarCeller. Historia de la Orden de Agustinos Recoletos, X (18081836). Madrid 1962.

Fidel DE BLAS. Labor evangélica de los Padres Agustinos Recoletos en las Islas Filipinas. Zaragoza 1910.

LUIS DE Jesús. Historia general de los religiosos descalzos del Orden de los Ermitaños del Gran Padre Agustín de la Congregación de España y de las Indias II. Madrid 1681.

Ma. Rita FerRarIs. The Beaterios for Native Women in Colonial Philippines. Manila 1987.

José García de SAN LoRenzo MÁrtiR. Un Plantel de Sampaguitas en el Vergel Recoleto Agustiniano o la Congregación de Agustinas Recoletas Misioneras de Filipinas. Zaragoza 1954.

Ricardo JARAUTA. Album de la Orden de Agustinos Recoletos. Zaragoza 1931. 
Patricio Marcellán. Provincia de San Nicolás de Tolentino de Agustinos Descalzos de la Congregación de España e Indias. Manila 1879.

Francisco MORENO. Instrucciones para las Hermanas Mantelatas, o Terceras del Orden de Recoletos de Nuestro Padre Agustín, y otros documentos referentes al Beaterio. Tambobong 1894.

Gregorio OchoA. Historia general de la Orden de los Agustinos Recoletos VIII. Zaragoza 1928.

Javier ORTIZ de la TABLA DucaSse. El Marqués de Ovando, Gobernador de Filipinas (1750-1754). Sevilla 1974.

Emilio Edgardo A. Quilatan, Emmanuel Luis A. Romanillos, Luciano P.R. SANTIAGo [Compilers]. Compilation of Documents on the Life, Virtues and Reputations of the Servants of God Mother Dionisia de Santa María and Mother Cecilia Rosa de Jesús. Manila 2002.

Emmanuel Luis A. Romanillos. The Augustinian Recollects in the Philippines. Hagiography and History. Quezon City 2001.

The Spires of San Sebastian. The story behind the image of the Virgen del Carmen and the only prefabricated all-steel church in Asia. Manila 1991.

Licinio RUIZ. Sinopsis histórica de la Provincia de San Nicolás de Tolentino de las Islas Filipinas de la Orden de Agustinos Recoletos, 2 vv. Manila 1925.

Francisco SÁDABA. Catálogo de los Religiosos Agustinos de la Provincia de San Nicolás de Tolentino de Filipinas desde 1606, en que llegó la primera misión, hasta nuestros días. Madrid 1906.

Luciano P.R. SANTIAgo. The Stars of Peace. The Talangpaz Sisters. Manila 2001.

. To Love and to Suffer. The Development of the Religious Congregations for Women in the Spanish Philippines. 1565-1898. Quezon City 2005.

Jesús SOBEJANO [ED.]. Los Agustinos Recoletos: 375 Años en las Islas Filipinas, 16061981. Manila 1982.

Bernardita VILLAMOR. Congregation of the Augustinian Recollect Sisters (AR). Past and Present. Manila 1991. 